Original Article

\title{
DETERMINATION OF ENERGY CONTENT, PHYTOCHEMICAL CONSTITUENTS AND ANTIOXIDANT ACTIVITY OF POTENTIAL WILD EDIBLE LEGUME; CANAVALIA ROSEA (SW.) DC. FROM NORTHERN KERALA
}

\author{
ASWATHI V., ABDUSSALAM A. K. \\ Department of Post Graduate Studies and Research in Botany, Sir Syed College, Taliparamba, Kannur University, Kannur, 671142 \\ Email: aswathybotany@rediffmail.com
}

Received: 12 Jun 2020, Revised and Accepted: 16 Aug 2020

\section{ABSTRACT}

Objective: Major objective of this study is to determine the calorific value and antioxidant activity of Canavaliarosea.

Methods: Petroleum ether extract of the seeds were tested qualitatively for twelve components. Calorific value in $\mathrm{kJ} / 100 \mathrm{~g}$ seed flour was determined based on the results of the proximate analysis. Enzymatic and non-enzymatic antioxidants were analyzed by standard procedures using UV-Visible Spectrophotometer.

Results: $C$. roseais a perennial creeper with roughly circular compound leaves. Flowers are brightly pink-purple, in racemes. It is having large fruits up to 8-12 cm, with brown dormant seeds inside. Seeds were collected from banks of 'Kabani' River (Panamaram) and from various tribal hamlets in Wayanad district, Kerela. Preliminary phytochemical screening reveals the presence of eight compounds such as, tannins,saponins, flavonoids, cardiac glycosides, terpenoids, phenols, coumarins and phlobatannins. The analysis of nutritive value of seed has a higher value of crude protein $(48.71 \%)$ and crude carbohydrate (34.07). The calorific value of seed material was $1529.9 \mathrm{~kJ} / 100 \mathrm{~g}$ seed flour. Enzymatic antioxidants superoxide dismutase $(38.134 \mathrm{u} / \mathrm{mg} \mathrm{fw})$ and catalase $(19.051 \mathrm{u} / \mathrm{mg} \mathrm{dw})$ then non-enzymatic antioxidants poly phenols $(12.81 \mathrm{u} / \mathrm{mg}$ dw) and ascorbic acid $(10.301 \mathrm{u} / \mathrm{mg} \mathrm{fw})$ were tested. All those tests show significant levels of antioxidants in the sample.

Conclusion: Hence, the present study providing details about the place of collection, ethnobotanical information, energy content and antioxidant activity of Canavaliarosea.

Keywords: Legume, Calorific value, Antioxidants, Canavaliarosea

(C) 2020 The Authors. Published by Innovare Academic Sciences Pvt Ltd. This is an open access article under the CC BY license (http://creativecommons.org/licenses/by/4.0/) DOI: http://dx.doi.org/10.22159/ijcpr.2020v12i5.39775. Journal homepage: https://innovareacademics.in/journals/index.php/ijcpr

\section{INTRODUCTION}

Legumes have been considered to be an economical dietary source of protein and are higher in protein than most other plant foods [1]. Consumption of legumes is recommended in the daily diet not only because of its protein; more than that legumes are also rich with other nutrients, dietary fibers and many useful phytochemicals [2].

Human interference such as industrialization, deforestation, pollution etc was badly affects the distribution of pantropicallegumes like Canavaliarosea, Canavaliamaritima, Canavaliacatharticaetc [3]. But, Canavaliarosea regenerates well, probably due to seed dormancy [4]. The genus Canavalia includes four subgenera with 51 species [5]. One of the most common members of this genus is Canavaliarosea [6] Perennial creeping legumes $C$. rosea and $C$. cathartica are dominant sand binders associated with rhizobia, endophytic fungi and arbuscular mycorrhizal fungi found abundantly on sand dunes in India $[7,8]$.

C. rosea is ecologically important in costal ecosystems, where it is a pioneer species on sand dunes [9]. Typical habits of $C$. rosea are beach, the backshore above the high tide mark, but it can sometimes climb over rocks and occasionally, it can grow near the shore of costal lagoons and roadsides [10].

Ethnobotanical inferences are available for the usage of root infusion, plant decoction, seed powder, leafpaste etc of $C$. rosea to treat pain and aches [11]. The young pods and seeds were occasionally used for edible purposes by forest dwellers living in Wayanad district of northern Kerala. They consume the seed meal along with their regular diet only after decanting several times and thorough cooking [12].

In this context, seeds of under-utilized tribal legume $C$. rosea were powdered and evaluated the energy content and antioxidant property. This under-exploited species (C. rosea) may serve as future food source $[13,14]$. So that it is important to investigate the nutritional quality and calorific value of this wild legume.

\section{MATERIALS AND METHODS}

\section{Collection of sample}

Seeds were collected from banks of Kabani River, Panamaram, Wayanad district, Kerela and moist deciduous forests near the vicinity of tribal hamlets situated in and around Batherytaluk, Wayanad district, Kerela (fig. 1). Samples were pooled together before analysis.

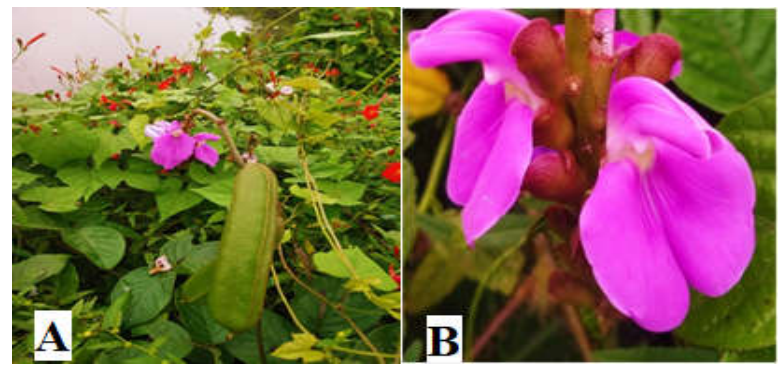

Fig. 1: A. Habit of C. rosea, B. inflorescence

Preparation of sample and qualitative analysis

Air-dried seeds (fig. 2) were weighed before putting into owen. Then incubate the seeds in an owen at $80^{\circ} \mathrm{C}$ for $24 \mathrm{~h}$. Then the sample was 
reweighed after cooling inside a desiccator. The average loss of weight was taken as the moisture content and it is expressed on percentage basis. About 50g of air dried and oven dried seeds along with their seed coat were ground in to fine powder separately. Care was taken to prevent the mixing up of samples. The petroleum ether extract of the sample was used to screen the presence of compounds like tannin, saponin, flavonoid etc by the protocol described by [15].

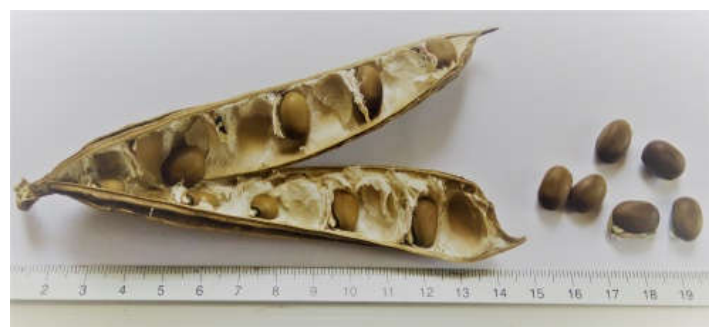

Fig. 2: Air dried pod with seeds

\section{Proximate analysis}

The nitrogen content was obtained by the micro Kjeldhal method, and then the total nitrogen content was multiplied by factor 6.25 to obtain the crude protein content [16]. The crude fat (ether extract content), crude fiber and ash content were determined by methods of AOAC [17]. The nitrogen-free extractives (NFE) or the total crude carbohydrate were calculated by the difference method suggested by Muller and Tobin [18]. Then the calorific value of $100 \mathrm{~g}$ sample was determined by methods according to Osborne and voogt [19].

\section{Antioxidant analysis}

\section{Enzymatic antioxidants}

\section{Enzyme extract preparation}

$0.5 \mathrm{~g}$ of seed flour was homogenized in $5 \mathrm{ml}$ of ice-cold $50 \mathrm{~m} \mathrm{~mol}$ potassium phosphate buffer (pH.7) by using a prechilled mortar and pestle. The extract was filtered and centrifuged (1000 rpm for 15 min). The supernatant was collected was then pooled for the enzyme assay [20]. The method used to determine the activity of catalase was proposed by Aebi [21]. It was observed as a decrease in absorbance at $240 \mathrm{~nm}$ for $1 \mathrm{~min}$ following the decomposition of hydrogen peroxide. The activity of superoxide dismutase was assayed according to the method of Ginnopolitis and Ries [22]. The absorbance was recorded at $560 \mathrm{~nm}$ against the blank.

\section{Non enzymatic antioxidants}

Ascorbic acid content activity was estimated by the method of Mukherjee and Choudhari [23]. Standard curve was made by a known concentration of ascorbic acid in 6\% trichloroacetic acid Total polyphenol content determination was done by the method suggested by Folin and Denis [24].

\section{Statistical analysis}

The statistical analysis was done by using Microsoft excel. Each set of data is an average of triplicates and it represents a mean \pm standard error.

\section{RESULTS AND DISCUSSION}

C. ensiformis, $C$. cathartic and C. gladiata, are some of the closest relatives of $C$. rosea [25]. Among the four species of Canavalia, $C$. roseais comparatively not much explored. Nutritional and antinutritional components in $C$. ensiformis were well studied [26]; and it contains components like tannin [27], saponin [28], phytic acid [29], and polyphenols [30] moderately in high quantities [31] Several studies on $C$. gladiata reveal the quantity [32] and the quality of secondary metabolites present in their seeds [33]. Most of the phytochemical components in $C$. cathartica were also analysed [34] and quantified earlier [35]

Canavalin A is the most studied plant lectin [36] found abundantly in genus Canavalia. It is a potential chemical constituent having wide range of applications in the field of isolation of immunoglobulins, blood group substances etc. And also has a role in anti-viral medicine [37]. Canavanine [38] and canaline are the specific analogue of arginine and are non-protein toxic amino acids [39] richly found in Canavalia species [40].

Every genus will definitely shows its own unique chemical profile during the qualitative tests. Among the twelve compounds tested Canavaliarosea shows the presence of saponin, tannin, flavonoid, terpenoid, phlobotannin, cardiac glycosides and total phenol (table 1). Many of these compounds are potentially significant against human pathogens [41]. Tannins are capable to inhibit digestive enzymes [42], while saponin can reduce the nutrient uptake [43]. Phenolics [44] and flavonoids are widely distributed in plants and are having powerful antioxidant activity [45], this legume is also rich in phenolics but most of the phenolic content was destroyed during cooking and steaming [30].

Table 1: Results of phytochemical screening of seeds of Canavaliarosea

\begin{tabular}{lll}
\hline S. No. & Phytochemical compounds & Petroleum ether extract of seed \\
\hline 1 & Tannin & + \\
2 & Saponin & + \\
3 & Flavanoids & + \\
4 & Quinones & - \\
5 & Glycosides & - \\
6 & Cardiac glycosides & + \\
7 & Terpenoids & + \\
8 & Phenols & + \\
9 & Coumarins & + \\
10 & Steroids & - \\
11 & Phobatannins & + \\
\hline
\end{tabular}

Components like cardiac glycosides, caumarins, terpenoids, phlorotannins, and tannins are secondary metabolites with or without antioxidant property and are undesirable from the nutritional point of view [46]. But these chemicals were synthesized and deposited in the plant tissue for protecting them from microbes or even from animal predators [47]. The presence of glycoside moieties like saponins, cardiac glycosides and flavonoids, which are known to have ability to inhibit or act against gastrointestinal infections are of pharmacological importance and give evidence to the use of the plant in ethnomedicine [48].
Coming to the results of proximate analysis (table 2) Canavaliarosea shows the highest amount of crude protein (48.71\%). The amount of moisture in the seeds is an important factor influencing seed viability. Generally seeds with higher moisture content will have a lower shelf life. Canavaliarosea is having $13.94 \%$ moisture content. The percentage of ash content is an indicator for the quality of mineral nutrients present [10], and these seeds possess $3.51 \%$ of ash content. Then these seeds possess $3.90 \%$ of crude fat and 9.81 $\%$ of crude fiber. Crude carbohydrate is also one among the nutrients, this sample contain $34.07 \%$ of the same. 
Table 2: Proximate composition

\begin{tabular}{ll}
\hline Components & Percentage \\
\hline \% Moisture content & $13.94 \pm 0.90$ \\
$\%$ Ash content & $3.51 \pm 0.01$ \\
$\%$ Crude fiber & $9.81 \pm 1.12$ \\
$\%$ Crude fat(Ether extract) & $3.90 \pm 0.8$ \\
\% Crude protein & $48.71 \pm 1.02$ \\
Calorific value is $1529.9 \mathrm{Kj} / 100 \mathrm{~g}$ seed flour. & 34.07 \\
\hline
\end{tabular}

On eating this legumes man and animals [49] will definitely get lots of natural antioxidants [50]. Antioxidants are substances which can inhibit oxidative damage by preventing the action of reactive oxygen species [51], and they are the first line of defense mechanism in neutralizing the free radicals [52]. Superoxide dismutase (SOD) and
Ascorbic acid were tested in fresh tissues while tests for Catalase and Polyphenols were done by using dry seed samples, and the results reveals that the seeds of $C$. rosea contain 38.134 units of SOD, 19.051 units of catalase, 12.81 units of polyphenols and 10.301 units of ascorbic acid per mg seed flour.

Table 3: Antioxidant composition

\begin{tabular}{lllll}
\hline Plant name & SOD (unit/mg FW) & Catalase (unit/mg DW) & Polyphenols (unit/mg DW) & Ascorbic acid (unit/mg FW) \\
\hline Canavaliarosea & $38.134 \pm 1.67$ & $19.051 \pm 1.01$ & $12.81 \pm 0.62$ & $10.301 \pm 1.13$ \\
\hline
\end{tabular}

\section{CONCLUSION}

This study helps us to conclude that the wild bean $C$. roseais, rich in phytochemicals thus should be exploited more as a medicinal proteinaceous food. This can also be used as a potential ingredient to formulate nutraceutical products for medicinal and veterinary applications. In vivo antioxidant activities of this beneficial wild bean along with the aspects of nutritional quality such as food efficiency ratio, net protein retention, protein retention efficiency, true digestibility, biological value etc need to be investigated further

\section{ACKNOWLEDGMENT}

The authors are extremely thankful to the Council of Scientific and Industrial Research (CSIR) for providing financial assistance.

\section{AUTHORS CONTRIBUTIONS}

All the authors have contributed equally.

\section{CONFLICT OF INTERESTS}

The authors have no conflict of interest to report.

\section{REFERENCES}

1. Food and agricultural organization of the United Nations Research approaches and methods for evaluating the protein content of foods. Report of an expert working group. Rome: FA0; 2014.

2. Kouris Blazos A, Belski R. Review article: health benefits of legumes and pulses with a focus on Australian sweet lupins. Asia Pac J Clin Nutr 2016;25:1-17.

3. D' Cunha M, Sridhar KR. Micropropagation of the wild legume Canavaliarosea (Sw.) DC from coastal sand dunes. Biol Lett 2011;48:85-96.

4. Arun AB, Raviraja N, Sridhar KR. Effect of temperature, salinity and burial on seed germination and seedling emergence of five costal sand dune legumes. Int J Ecol Environ Sci 2001;27:23-9.

5. Smartt J. Grain legumes. Cambridge University Press: Cambridge UK; 1990. p. 301-9.

6. Mendoza Gonzalez G, Luisa MM, Lithgow D. Biological flora of costal dunes and wetlands: Canavaliarosea (Sw) DC. J Costal Res 2014;30:697-713.

7. Chen WM, Lee TM, Lam CC, Cheng CP. Characterization of halotolerant rhizobia isolated from root nodules of Canavaliarosea from seaside areas. FEMS Microbiol Ecol 2000;34:9-16

8. Seena S, Sridhar KR. Nutritional and microbiological features of little known legumes, Canavaliacathartica thouars and Canavalia maritime thouars of the southwest coast of India. Curr Sci 2006;90:1638-50.
9. D’Arcy WC. Canavalia. In: Woodson R, Schery RW. (eds.) Flora de Panama.(Leguminosae). Annals of the Missouri Botanical Garden 1980;67:562-71.

10. Tijani KB, Alfa AA, Momoh A, Sezor AA. Phytochemical and nutraceutical potentials of beach bean (Canavaliarosea) Sw. DC growth anyigba, kogi state, Nigeria. Asian J Med Health 2019;17:1-9.

11. Bhagya B, Srighar KR. Ethnobiology of coastal sand dune legumes of the southwest coast of India. Indian J Trad Knowl 2009;8:611-20.

12. Thangadurai D, Viswanathan MB, Ramesh N. The chemical composition and nutritional evaluation of Canavaliavirosa: perennial wild bean from Eastern Ghats of Peninsular India. Eur Food Res Technol 2001;213:456-9.

13. Arun AB, Beena KR, Raviraja NS, Sridhar KR. Costal sand dunesa neglected ecosystem. Curr Sci 1999;77:19-21.

14. Seena S, Sridhar KR. Nutrient composition and biological evaluation of an unconventional legume, Canavaliacathartica of mangroves. Int J Food Sci Nutr 2004;55:615-25.

15. Harborne J. Phytochemical methods. Chapman and Hill, Ltd London; 1973. p. 49-188.

16. Humphries FC. Mineral composition and ash analysis. In: Paech K, Tracey MV. (eds) Modern methods of plant analysis. Springer, Berlin Heidelberg New York; 1956. p. 468-502.

17. AOAC. Official methods of analysis. Association of Official Analytical Chemists, Washington; 1970.

18. Muller HG, Tobin G. Nutrition and food processing. Croom Helm, London; 1980.

19. Osborne DR, Voogt P. The analysis of nutrients in foods, Academic Press: New York; 1978. p. 239-40.

20. Yin D, Chen S, Chen F. Morphological and physiological responses of two Chrysanthemum cultivars differing in their tolerance to waterlogging. Environ Exp Bot 2009;67:87-93.

21. Aebi H. Catalase in vitro. Methods Enzymol 1984;105:12-6.

22. Giannopolitis CN, Reis SK, Superoxide Dismutase I. Occurrence in higher plants. Plant Physiol 1997;59:309-14.

23. Mukherjee SP, Choudhari MA. Implications of water stressinduced changes in the levels of endogenous ascorbic acid and hydrogen peroxide in Vigna seedlings. Physiol Plant 1983;58:166-70.

24. Folin 0, Denis W. The diagnostic value of uric acid determinations in blood. Arch Intern Med 1915;16:33-7.

25. Sridhar KR, Seena S. Nutritional and antinutritional significance of four unconventional legumes of the genus canavaliaacmparative study. Food Chem 2006;99:267-88.

26. Agbede JO, Aletor VA. Studies of the chemical composition and protein quality evaluation of differently processed Canavaliaensiformis and Mucunapruriens seed flours. J Food Compost Anal 2005;18:89-103. 
27. Belmar R, Nava Montero R, Sandoval Castero C, Mc Nab JM. Jack bean (Canavaliaensiformis L. DC) in poultry diets: antinutritional factors and detoxification studies-a review. World Pollution Sci J 1999;55:37-59.

28. Bressani R, Sosa JL. Effect of processing on the nutritive value of canavalia Jack beans (Canavaliaensiformis L. DC). Plant Foods Hum Nutr 1990;40:207-14.

29. D Mello JPF, Walker AG. Detoxification of Jack beans (Canavaliaensiformis): studies with young chick. Animal Feed Sci Tech 1991;33:117-27.

30. Babar VS, Chavan JK, Kadam SS. Effects of heat treatments and germination on trypsin inhibitor activity and polyphenols in Jack beans (Canavaliaensiformis L. DC). Plant Foods Hum Nutr 1988;38:319-24

31. D Mello JPF, Walker AG, Noble E. Effects of dietary supplements on the nutritive value of Jack beans (Canavaliaensiformis) for the young chick. British Pollutions Sci 1990;31:759-68.

32. Siddhuraju P, Becker K. Species/variety differences in biochemical composition and nutritional value of Indian tribal legume of the genus canavalia. Nahrung 2001;45:224-33.

33. Bressani R, Brenes RS, Gracia A, Elias LG. Chemical composition, amino acid content and protein quality of Canavalia spp. seeds. J Sci Food Agric 1987;40:17-23.

34. Mohan VR, Janardhanan K. The biochemical composition and nutrient assessment of less known pulses of the genus canavalia. Int J Food Sci Nutr 1994;45:255-62.

35. Arun AB, Sridhar KR, Raviraja NS, Schmidt E, Jung K Nutritional and antinutritional components of Canavalia spp. seeds from the west coast sand dunes of India. Plant Foods Hum Nutr 2003;58:1-13.

36. Sumner JB, Howell SF. Identification of the hemagglutinin of jack bean with con A. J Bacteriol 1936;32:227-37.

37. Surolia A, Prakash N, Bishayee S, Bachhawat BK. Isolation and comparative physicochemical studies of cincanavalin a from Canavaliaensiformis and Canavaliagladiata. Indian J Biochem Biophy 1973;10:145-8.

38. Bell EA. Canavanine in the leguminosae. Biochem 1960;75:618-20.

39. Rosenthal GA. The biochemical basis for the deleterious effects of L-canavanine. Phytochemistry 1991;30:1055-8.
40. Rodrigues BF, Torne SG. Estimation of canavanine in the seeds of three canavalia species. Trop Sci 1992;32:319-20.

41. Kim DO, Jeong SW, Lee CY. Antioxidant capacity of phenolic phytochemicals from various cultivars of plums. Food Chem 2003;81:321-6.

42. Jambunathan R, Singh U. Grain quality of pogeonpea. In: Proceedings of the International Workshop on Pigeonpea, ICRISAT, Hydrrabad 1981;1:351-6.

43. Cheeke PR. Nutritional and physiological implications of saponins: a review. Canadian J Anim Sci 1971;51:621-3.

44. Fang YZ, Yang $\mathrm{S}, \mathrm{Wu}$ G. Free radicals, antioxidants and nutrition. Nutr J 2002;18:872-9.

45. Kar A. Pharmacognosy and biotechnology. New Age International, New Delhi; 2007. p. 332-600.

46. Arinathan V, Mohan VR, De Britto AJ. Chemical composition of certain tribal pulses in South India. Int J Food Sci Nutr 2003;54:209-17.

47. Tijani KB, Alfa AA, Momoh A, Sezor AA. Phytochemical and nutraceutical potentials of beach bean (Canavaliarosea SW.) DC grown in Anyigba, Kogi state, Nigeria. Asian J Med Health 2019;17:1-9.

48. Prabhu S, Raj LJM, Britto SJ, Senthilkumar SR. Antibacterial activity and preliminary phytochemical analysis of leaf extract of Canavaliarosea (Sw.) DC. (Beach bean). Int J Res Pharm Sci 2010;4:428-34.

49. Seena S, Sridhar KR, Bhagya B. Biochemical and biological evaluation of an unconventional legume, Canavaliamaritima of coastal sand dunes of India. Trop Subtrop Agroecosyst 2005;5:1-14.

50. Nair P. Health benefits of sword bean; 2014. Available from: http://www.valuefood.info/1999/health-benefits-of-swordbean. Last accessed on 05 May 2020]

51. Olugboyegai SK, Edem AR. Comparative phytochemicals and in vitro antioxidative effects of Jack beans (Canavaliaensiformis) and sword bean (Canavaliagladiata). Annals Food Sci Tech 2018;19:499-505.

52. Saraswathi K, Rajesh V, Saranya R, Arumugam P. GC-MS phytochemical analysis and in vitro antioxidant activities of leaves of canavaliacathartica thouras. J Phytopharmacol 2018;7:263-9. 